\title{
Need Assessment of Socioscientific Issues-Based (SSI) on the Scientific Literacy Assessment Instrument towards the Environmental Pollution Topic
}

\author{
Novi Ayu Safira ${ }^{1}$, Sunyono ${ }^{2}$, Undang Rosidin ${ }^{3}$ \\ \{noviisafiraa@gmail.com ${ }^{1}$ \}

\begin{abstract}
Science Education Magister Program, Lampung University, Indonesia ${ }^{1}$, Chemistry Education, Lampung University, Indonesia ${ }^{2}$, Physics Education, Lampung University, Indonesia ${ }^{3}$
\end{abstract}

\begin{abstract}
This study aims to analyze the needs of Socioscientific Issues (SSI) based scientific literacy assessment instruments on environmental pollution topic. The method used in this study is a survey method. The subjects in this study consisted of one hundred seventh grade students and thirty science teachers from ten public and private junior high schools in the cities of Bandar Lampung and Metro. The data collection technique was carried out using a questionnaire and a test of students' scientific literacy skills to determine whether or not SSI-based scientific literacy assessment instruments were needed on environmental pollution material. The results showed that, (1) $73 \%$ of teachers had not yet assessed students' scientific literacy skills; (2) $87 \%$ of teachers had never given SSI-based questions on environmental pollution material to measure students' scientific literacy skills; (3) $80 \%$ of students felt that the teacher had never given SSI-based scientific literacy questions to environmental pollution material; (4) as much as $100 \%$ of teachers expect that there is a need to develop an SSI-based science literacy assessment instrument on environmental pollution topic; (5) and the students' scores are still below the average target score of the 2015 PISA assessment which shows the need for the development of an SSIbased science literacy assessment instrument on environmental pollution topic.
\end{abstract}

Keywords: Socioscientific Issues, Scientific Literacy, environmental pollution.

\section{Introduction}

Science education must be developed in accordance with the characteristics and functions through the steps and the learning process that refers to the ability of the 21 st century. Specifically in the ability of the 21 st century, students must engage in higher-order thinking carried out with active learning that is closely related to solving real world problems related to nature [1]. One of the abilities needed by the 21st century to solve real-world problems based on the mastery of scientific understanding is scientific literacy [2]. This ability has become the topic of much discussion as an ability that can participate in solving real-world problems through understanding science and technology based on mastery of mathematics, physics, chemistry, biology, and the environment [3].

Science literacy is defined as the ability to use scientific knowledge to explain and predict natural phenomena in order to overcome natural problems through scientific methods [4]. The ability of scientific literacy is the ability to live in an era where scientific knowledge is the foundation of everyday life [5]. With the ability of scientific literacy, students will get used to using science concepts in making everyday decisions through process skills by understanding 
the relationships between science, technology and society, social development and producing useful scientific products [6]. Educating students to have scientific literacy is a major goal in every science education reform [7]. Based on this, the scientific literacy ability needs to be trained and developed in students in the science learning process, looking at the importance of thinking and acting skills that involve mastering thinking and using scientific thinking in recognizing and responding to social issues [8].

In fact, until now the ability of scientific literacy skills has not been programmed by the teachers in schools. This is reinforced by the results of the Study for International Student Assessment (PISA) study which shows that Indonesian students were ranked 60 out of 65 countries in 2009, ranked 64 out of 65 countries in 2012, and the most recent PISA results namely in 2015 Indonesian students received ranked 69 out of 79 countries [4]. The low achievement of students' science is because the problems contained in PISA require higherorder thinking skills by solving real problems in daily life. Indonesian students only master questions that are routine, simple computing, and measure knowledge of everyday contextual facts. In addition, the teaching and learning process carried out is still oriented to the mastery of science concepts alone [9]. So, it is necessary to strengthen students' scientific abilities in using science knowledge [4] which can be trained with scientific literacy skills [9].

One approach to learning that can train and develop students' scientific literacy skills is by learning based on socio scientific issues (SSI). SSI become important in science education because they occupy a central role in increasing scientific literacy [10]. SSI can be defined as an issue that describes social problems in society related to the conceptual, procedural, or technological context of science [11]. SSI provides contextual learning situations that have the opportunity for the development of argumentative scientific skills, exploration of moral issues, the development of moral reasoning and reflective judgment abilities [12] so students are able to make decisions on problems that exist in their social environment in a scientific and socially valuable manner.

Besides the need for the use of SSI-based learning that can develop students 'scientific literacy skills, the use of measuring instruments/tests is one of the important things in practicing students' scientific literacy abilities. Currently the measuring tools/tests used are still focused on questions that have not measured the scientific literacy skills of students and are not based on SSI. Even though one way to find out whether students already have the ability of scientific literacy is to do an assessment. The assessment is used to conduct an evaluation, namely as a measuring tool that compares something with one measure and to judge by making decisions on something with good and bad measures [13].

Assessment is a process or activity that is continuous and systematic to collect information about the process and learning outcomes of students in order to make decisions based on certain criteria and scales [14]. Assessment is an important part in the learning process because of the assessment process the teacher can obtain a portrait or profile of students' abilities in achieving basic competencies [15]. Assessment of scientific literacy skills can be carried out by providing instruments in the form of multiple choice test questions and descriptions to students who each question must pay attention to four major aspects according to PISA, namely aspects of context, knowledge, competence, and attitude [4].

Aspects of the context of scientific literacy include personal, local / national, and global issues both now and in the past. The aspect of knowledge in scientific literacy is explained as an understanding of the main facts, concepts, and explanatory theories that form the basis of scientific knowledge. The competency aspect is understood as the ability to explain phenomena scientifically, evaluate and design scientific investigations, and interpret data and evidence 
scientifically. Furthermore, the attitude domain is explained as the attitude towards science which is shown by the students' interest in science and technology [4].

The context aspect is needed to support the competency domain while the competency domain is influenced by the attitude and knowledge domain. Based on this, in assessing the ability of scientific literacy, the questions on the test instrument only focus on the domain competency indicator that explains scientific phenomena, evaluates and designs scientific questions, and interprets scientific data and evidence [4].

In addition to paying attention to the aspect of scientific literacy, test questions used in conducting assessments must be designed with SSI-based questions. SSI is important in the field of science education because it can be used as a tool to increase the ability of scientific literacy [16]. SSI-based test questions must include questions that can: (1) present the issue from the standpoint of science knowledge, (2) evaluate the social science issues presented; (3) assess local, national and global impacts, and (4) make decisions related to social science issues [17], where the four stages of the SSI are believed to be able to measure students' scientific literacy abilities. By encouraging the involvement of large learners through social problems that are relevant and rooted in scientific disciplines, SSI has demonstrated its potential for problem solving and the acquisition of scientific content [18].

Several studies have been carried out in an effort to develop an instrument of scientific literacy ability assessment which will be the basis of research for the use of SSI-based scientific literacy assessment instruments on environmental pollution material. Environmental pollution topic is used because it is a suitable material based on SSI. This research was conducted for science teachers and junior high school students aimed at analyzing the needs of SSI-based science literacy assessment instruments on environmental pollution topic in the learning process.

\section{Method}

The method used in this study is a survey method. The subjects of this study were one hundred seventh grade junior high school students and thirty science teachers from ten public and private junior high schools in the cities of Bandar Lampung and Metro. Data collection was carried out using a questionnaire technique on the need for an SSI-based science literacy assessment instrument on environmental pollution material and an analysis technique for early scientific literacy skills of junior high school students given through students' scientific literacy ability tests of PISA questions. Next, the data obtained from the responses of teachers and students were analyzed using the following formula:

$$
\% J_{i}=\frac{\Sigma J_{i}}{\Sigma^{N}} \times 100 \%
$$

Where \% $J i$ is the percentage of choice of answer $i, \sum J i$ is the number of respondents who answered answer $i$, and $\sum N$ is the total number of respondents.

The technique of analyzing the students 'initial ability in scientific literacy test is done by calculating the students' answers on each item of scientific literacy indicator test using the following formula:

$$
\% X_{\text {in }}=\frac{\sum s}{\text { smaks }} \times 100 \%
$$

Where $\% X_{\text {in }}$ is the percentage of answers to the PISA literacy questions, $\sum S$ is the total answer score and Smaks is the maximum expected score. Then the results of the analysis of the percentage of answer scores are interpreted based on the item scoring at PISA 2015. 


\section{Result and Discussion}

Based on the results of the questionnaire, where $78 \%$ of students find it difficult to answer questions relating to explaining phenomena scientifically, $86 \%$ of students find it difficult to answer questions relating to evaluating and designing scientific investigations, and $78 \%$ of students feel difficulty in answering questions related to interpreting data and scientific evidence. The results of the questionnaire analysis concluded that the difficulty of students in answering questions related to scientific phenomena, evaluating and designing scientific investigations, and interpreting data and scientific evidence due to the lack of students' habits in answering questions involving SSI so that the scientific literacy of students is less trained. This is reinforced from the data of $80 \%$ of students feel the teacher has never given SSI-based scientific literacy questions on environmental pollution material.

Tabel 1. Percentage of Students Recapitulation Questionnaire Analysis of Development of SSI-Based Science Literacy Assessment Instrument Needs on the Topic of Environmental Pollution.

\begin{tabular}{|c|c|c|}
\hline \multirow{2}{*}{ Questions } & \multicolumn{2}{|c|}{ Student's Response } \\
\hline & Yes & No \\
\hline Students find difficulty in understanding science topics & $66 \%$ & $34 \%$ \\
\hline Students do learning by using socioscientific issues (SSI) & $24 \%$ & $76 \%$ \\
\hline The teacher helps in increasing students' scientific literacy skills & $40 \%$ & $60 \%$ \\
\hline $\begin{array}{l}\text { The teacher has given science material questions related to science literacy } \\
\text { and SSI }\end{array}$ & $34 \%$ & $66 \%$ \\
\hline $\begin{array}{l}\text { Students have difficulty answering questions related to explaining the } \\
\text { phenomenon scientifically }\end{array}$ & $78 \%$ & $22 \%$ \\
\hline $\begin{array}{l}\text { Students have difficulty answering questions related to evaluating and } \\
\text { designing scientific investigations }\end{array}$ & $86 \%$ & $14 \%$ \\
\hline $\begin{array}{l}\text { Students have difficulty answering questions related to interpreting data and } \\
\text { scientific evidence }\end{array}$ & $78 \%$ & $22 \%$ \\
\hline The teacher gives SSI-based science literacy questions & $22 \%$ & $78 \%$ \\
\hline $\begin{array}{l}\text { The teacher gives SSI-based science literacy questions on environmental } \\
\text { pollution material }\end{array}$ & $20 \%$ & $80 \%$ \\
\hline
\end{tabular}

The results of the needs questionnaire analysis also showed that $73 \%$ of teachers had not yet conducted an assessment of environmental pollution material that measured students' scientific literacy skills and as many as $87 \%$ of teachers stated that the assessment instruments used in the classroom on environmental pollution material had not displayed phenomena based on issues so social science can not measure the scientific literacy ability of students. Moreover, $100 \%$ of teachers expect the development of SSI-based science literacy assessment instruments on environmental pollution material. Development of an SSI-based science literacy assessment instrument is expected to be in the form of questions that can (1) present the issue from the standpoint of scientific knowledge/scientific background; (2) evaluating the social science issues presented/evaluation of information; (3) assess local, national and global impacts/local, national, and global dimension; (4) as well as making decisions related to social science issues/decision making [17], where SSI is important in the field of science education because it can be used as a tool to increase the ability of scientific literacy [19]. 
Tabel 2. Percentage of Teachers Recapitulation Questionnaire Analysis of Development of SSI-Based Science Literacy Assessment Instrument Needs on the Topic of Environmental Pollution.

\begin{tabular}{|c|c|c|}
\hline \multirow{2}{*}{ Questions } & \multicolumn{2}{|c|}{ Teacher's Respon } \\
\hline & Yes & No \\
\hline The teacher knows learning based on SSI & $27 \%$ & $73 \%$ \\
\hline The teacher used SSI based learning in science learning & $27 \%$ & $73 \%$ \\
\hline The teacher knows about the ability of scientific literacy & $77 \%$ & $23 \%$ \\
\hline The teacher has practiced the science literacy skills of students & $43 \%$ & $57 \%$ \\
\hline Students' scientific literacy skills need to be assessed & $73 \%$ & $27 \%$ \\
\hline $\begin{array}{l}\text { The teacher has conducted an assessment of students' scientific literacy } \\
\text { skills }\end{array}$ & $27 \%$ & $73 \%$ \\
\hline The scientific literacy skills of students are as expected & $20 \%$ & $80 \%$ \\
\hline $\begin{array}{l}\text { The teacher has conducted an assessment of environmental pollution topic } \\
\text { that measures the ability of students' scientific literacy }\end{array}$ & $27 \%$ & $73 \%$ \\
\hline $\begin{array}{l}\text { The teacher once gave SSI-based questions on environmental pollution } \\
\text { topic to measure students' scientific literacy skills }\end{array}$ & $13 \%$ & $87 \%$ \\
\hline $\begin{array}{l}\text { The development of SSI-based science literacy assessment instruments for } \\
\text { environmental pollution is needed }\end{array}$ & $100 \%$ & $0 \%$ \\
\hline
\end{tabular}

While based on the results of the analysis of students' scientific literacy ability tests given to one hundred students, it shows that the three indicators of scientific literacy in the aspects of competence which include explaining phenomena scientifically, evaluating and designing scientific investigations, and interpreting data and scientific evidence are still below average. the average PISA assessment target score of 2015. On the indicators explaining the phenomenon scientifically obtained a score of $33.20 \%$ where the target score of the 2015 PISA assessment is $40 \%-50 \%$. Indicators evaluating and designing scientific investigations obtained a score of $15.40 \%$ with a 2015 PISA assessment score target of $20 \%-30 \%$ and an indicator interpreting data and scientific evidence obtained a score of $23.40 \%$ where the 2015 PISA assessment score target of $30 \%-40 \%$.

Tabel 3. Percentage score of initial ability of scientific literacy of students

\begin{tabular}{lcc}
\hline \multirow{2}{*}{ Indicators of Science Literacy Competence } & \multicolumn{2}{c}{ Percentage } \\
\cline { 2 - 3 } & $\begin{array}{c}\text { Student } \\
\text { Score }\end{array}$ & $\begin{array}{c}\text { PISA 2015 } \\
\text { Target Score }\end{array}$ \\
\hline Explain Phenomena Scientifically & $33,20 \%$ & $40-50 \%$ \\
Evaluate and design scientific investigations & $15,40 \%$ & $20-30 \%$ \\
Interpret data and scientific evidence & $23,40 \%$ & $30-40 \%$ \\
\hline
\end{tabular}

The low test results of scientific literacy skills of students due to test questions that are often given can not measure the scientific literacy skills of students. The test questions given do not refer to the questions that present phenomena based on sociocultural issues and are only in the form of test questions that are routine, simple computing, and only measure knowledge and facts that have a daily context. SSI-based science literacy assessment instruments in the form of phenomena, images, and articles that can develop students' scientific literacy [20]. Through SSI, issues or problems in social life that are conceptually closely related to science can find relative answer solutions so as to stimulate intellectual, moral and ethical development, and awareness of the relationship between science and social life [21] which can directly measure and develop students' scientific literacy skills. 


\section{Conclusion}

The results of this study will be used as a basis for developing a scientific literacy assessment instrument based on socioscientific issues (SSI) on environmental pollution material. As many as $100 \%$ of teachers stated that they needed to develop an SSI-based science literacy assessment instrument on environmental pollution material. The teacher hopes that the assessment instruments developed later can measure students' scientific literacy abilities which include indicators explaining phenomena scientifically, evaluating and designing scientific investigations, and interpreting data and scientific evidence obtained from (1) presenting issues from the standpoint of scientific knowledge/scientific background; (2) evaluating the social science issues presented/evaluation of information; (3) assess local, national and global impacts/local, national, and global dimension; (4) and make decisions related to social science issues/decision making.

\section{References}

[1] Rahmasiwi, A., Susilo, H., \& Suwono, H. Pengaruh pembelajaran diskusi kelas menggunakan isu sosiosains terhadap literasi sains mahasiswa baru pada kemampuan akademik berbeda. Jurnal Pendidikan. 2018. 3 980-989.

[2] Liu, X. Beyond science literacy: science and the public International. Journal of Environtmental and Science Education. 2009. 4 301-311.

[3] Cardwell, V. B. Literacy: what level for food, land, natural, resource, and environtment?. Journal of Natural Resources and Life Science Education. 2005. 31 1421-1445.

[4] OECD. PISA 2015 Assessment and analytical framework: mathematics, reading, science, problem solving, and financial literacy. Paris: OECD Publishing. 2016.

[5] Gultape, N., \& Kilic, Z. Effect of scientific argumentation on the development of scientific process skills in the context of teaching chemistry. International Journal of Enviromental and Science Education. 2015. 10 111-132.

[6] Laugksch, R. Scientific literacy: a conceptual overview. Science Education. 2000. 84 71-94.

[7] DeBoer, G. E. Scientific literacy: another look at its historical and contemporary meanings and its relationship to science education reform. Journal of Research in Science Teaching. 2000. 37 582601.

[8] Vieira, R. M. \& Tenreiro, V. C. Fostering scientific literacy and critical thinking in elementary science education. International Journal of Science and Mathematics Education. 2014. 14 659-680.

[9] Suwono, H., Rizkita, L., \& Susilo, H. Peningkatan literasi saintifik siswa SMA melalui pembelajaran biologi berbasis masalah sosiosains. Jurnal Ilmu Pendidikan. 2015. 21 136-144

[10] Merghli, K. Contemporary science education research: science literacy and social aspect of science. Turkey: PEGEM Akademi. 2009.

[11] Sadler, T. D. \& Zeidler, D. L. The morality of socioscientific issues: construal and resolution of genetic engineering dilemmas. Science Education. 2004.88 4-27.

[12] Zeidler, D. L. \& Nichols, B. H. Socioscientific issues: theory and practice. Journal of elementary science education. 2009. 21 49-58.

[13] Arikunto, S. Prosedur penelitian suatu pendekatan praktik. Jakarta: Rineka Cipta. 2016.

[14] Adawiyah, R. \& Wisudawati, A. W. Pengembangan instrumen tes berbasis literasi sains: menilai pemahaman fenomena ilmiah mengenai energi. Indonesia Journal of Curriculum and Educational Technology Studies. 2017. 5 112-121.

[15] Uno, B. H. \& Koni, S. Assesment pembelajaran. Jakarta: Bumi Aksara. 2013.

[16] Sadler, T. D. Informal reasoning regrarding socioscientific issues: a critical review of research. Journal of Research in Science Teaching. 2004. 41 513-536.

[17] Yuliastini, I., Rahayu, S., \& Fajaroh, F. POGIL berkonteks socio sciencetific issus (SSI) dan literasi kimia siswa SMK Pros. Semnas Pendidikan IPA Pascasarjana UM. 2016. 601-604. 
[18] Zeidler, D. L., Sadler, T. D., Applebaum, S., \& Callahan, B. E. Advancing reflective judgment through socioscientific isuues. Journal of Research in Science Teaching. 2009. 46 74-101.

[19] Zeidler, D. L., Sadler, T. D., Simmons, M. L., \& Howes, E. V. Beyond STS: A research-based framework for socioscientific issues education. Science Education. 2005. 89357 - 377.

[20] Ridwan, M. S., Mardhiyyah, L. A., \& Rusilowati, A. Pengembangan instrumen asesmen dengan pendekatan konstektual untuk mengukur level literasi sains siswa. Seminar Nasional Evaluasi Pendidikan Tahun 2013. 2013.

[21] Anagun, S. S. \& Ozden, M. Teacher candidates' perceptions regarding socio-scientific issues and their competencies in using socio-scientific issues in science and technology instruction. Journal of Procedia Social and Behavioral Science. 2010. 9 981-985 